|Araştırma Makalesi / Research Article|

\title{
Analysis of the Studies on E-learning Acceptance of Learners in the Middle East and the Proposal of an Extended Technology Acceptance Model
}

\section{Orta Doğu'da Öğrenicilerin E-Öğrenme Kabulü ile İlgili Yapılan Çalışmaların Analizi ve Genişletilmiş Bir Teknoloji Kabul Modelinin Önerilmesi}

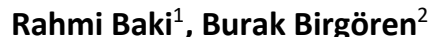

\author{
Anahtar Kelimeler \\ e-öğrenme \\ uzaktan eğitim \\ kültürel farklılıklar \\ teknoloji kabul modeli \\ öğrenme stratejileri

\section{Keywords \\ e-learning \\ distance education \\ cultural differences \\ technology acceptance \\ model \\ learning strategies}

Başvuru Tarihi/Received

21.01.2020

Kabul Tarihi /Accepted

28.08.2020

\section{Öz}

E-öğrenme uygulamaları, kullanıcıların coğrafi bölgelerine ve kültürel kökenlerine bağlı olarak çeşitli beklenti, tutum ve ihtiyaçlara yol açabilir. Bu nedenle, bireylerin kültürel ve demografik özelliklerini dikkate alarak e-öğrenme sistemlerinin tasarlanması, etkili bir öğrenme ortamı için çok önemlidir. Çalışmada, 10 farklı Orta Doğu ülkesinde kullanıcıların e-öğrenme kabul özelliklerini değerlendiren 44 araştırma incelenmiştir. Bu araştırmalarda 45 dışsal değişken, Teknoloji Kabul Modelinin (TKM) inanç değişkenleri olan Algılanan Fayda (AF) ve Algılanan Kullanım Kolaylığının (AKK) ön belirleyicileri olarak önerilmektedir. Dışsal değişkenler inanç değişkenlerinin öncülü olarak 75 hipotezde 155 kez test edilmiştir. Yapılan bölgeye dayalı literatür taraması sayesinde; Ortadoğu'da kullanıcıların sistem kabulüne neden olan faktörlerin belirlenmesi amaçlanmaktadır. Sonuç olarak, en sık kabul edilen hipotezlerin orijinal TKM'ne dahil edilmesiyle Ortadoğu için genişletilmiş bir TKM önerilmiştir.

\section{Abstract}

E-learning applications can result in various expectations, attitudes and needs based on the users' geographical regions and cultural roots, therefore, design of e-learning systems by taking into account the individuals' cultural and demographic attributes is crucial for an effective learning environment. This study considers 44 researches that assess users' e-learning acceptance characteristics in 10 different Middle Eastern countries, where 45 external variables are proposed as predeterminants of Perceived Usefulness (PU) and Perceived Ease of Use (PEOU), both of which are Technology Acceptance Model's (TAM) belief components. 75 hypotheses are tested 155 times where these external variables are presented to be the antecedents of the belief components. With the help of a region-based literature review; it is aimed to identify the factors causing users' system acceptance in the Middle East. As a result, an extended TAM is proposed for the Middle East by incorporating the most frequently accepted hypotheses into the original TAM.

${ }^{1}$ Corresponding Author, Aksaray University, Faculty of Economics and Administrative Sciences, Management Information Systems Department, Aksaray, Turkey; https://orcid.org/0000-0003-0981-5006 


\section{INTRODUCTION}

Current developments in information technologies have a substantial conducive impact on organizations' working practices and have forced organizations into improving their time, cost and quality management skills. One of the most substantial shifts in the organizations in learning sector is caused by the advent of distance education systems. E-learning is simply the utilization of telecommunication technologies to convey information for learning and is being used extensively from the nineties onwards (Lee, Yoon \& Lee, 2009).

E-learning, like conventional education, is not tangible since it is not designed and structured for use in a pre-defined span of time (Trentin, 1997). These systems provide flexibility to students in terms of time and space, aiming to better ensure for the needs of geographically scattered students with conflicting schedules (Pituch \& Lee, 2006). Nevertheless, the system does not prove helpful if it is not actively used, since, the adoption and utilization of information technologies is critical for taking advantage of system's benefits (Karahanna, Straub \& Chervany, 1999). Identification and structuring of the conditions taken up by users in information technologies is a prioritized subject in relevant research (Venkatesh \& Davis, 2000), triggering many academics to analyse the reasons of user acceptance via taking into account various theories, Technology Acceptance Model (TAM) being the most frequently used one (Sumak, Hericko \& Pusnik, 2011). TAM proposes that two belief structures, PU and PEOU determine usage, while external variables acting as antecedents of these two components shed light on the triggering effects of PU and PEOU. (Legris, Ingham \& Collerette, 2003).

Today, e-learning systems are being used in various regions and cultures, as each geographical and cultural identity shapes the reasons for e-learning acceptance. Since various factors have impacts differing from culture to culture and region to region, different strategies should be embraced in facing problems in each culture (Mohammadi, 2015.a). This study provides an analysis of research studying e-learning acceptance of users in the Middle East using TAM. It identifies the external variables investigated in the literature and their relationships with PU and PEOU. In addition, it deducts the determinants and hypotheses that are frequently accepted as having significant effects on these belief variables from the literature.

Many countries in the Middle East region are working on modernization programs to diversify their economies and meet human capital needs in the future labour force. Professional programs are gaining popularity and the digital revolution will play a major role in this period. Gulf Cooperation Council countries are actively working to reduce their commitment to both the oiloriented economy and the migrant labour force (Docebo, 2016). Considering that e-learning systems provide easy access to information not only to a registered group of learners, but also to all segments of the society, eliminating the necessity of users to be in the same physical environment, and providing opportunities for educators and students to choose time and space; they will provide a great financial advantage especially for the developing countries in the region.

Related research is selected after a detailed review of Google Scholar, Science Direct, ProQuest Dissertations \& Thesis Global, EBSCOhost and Taylor \& Francis databases. The selection criteria are as follows; (i) The re-search should analyse users' e-learning acceptance through TAM, (ii) The model proposed in the research should be empirically tested in a Middle Eastern country, (iii) The model proposed in the research should include at least one of the PU or PEOU variables, which are the belief structures, (iv) The study must be recent.

The scope of the literature review consists of 39 publications and 5 briefs, all of which were conducted in the Middle Eastern countries to identify the pre-determinants of PU and PEOU. 75 hypotheses regarding the relation-ship of these variables with belief structures were tested 155 times. The most generally accepted hypotheses are proposed to be included in an extended TAM model for the Middle East.

\section{E-learning Acceptance}

Information technologies have become necessary for users and firms (Baki, 2019). The ever-increasing importance of education in everyday lives has been forcing organizations to develop new learning strategies, one of the results being the emergence of elearning. E-learning is simply a web-based system comprising communication, cooperation, education, learning and transferring of information with the goal of creating positive spill overs in the education and corporate sectors (Kelly \& Diane, 2003). E-learning is being used extensively in education from 1990s onwards and have become an indispensable part of the education sector where there is intense competition (Lee et al., 2009). It draws its strength from removing one-dimensional learning approaches and providing users the chance to direct and customize content (Pantezis, 2002). The needs of geographically dispersed students can be met more effectively. It allows students review the courses as many times as they like. Nevertheless, if users do not adopt this system, they will not be able to benefit from it, creating a negative return on investments, because information systems only bear the potential to improve organizational performance if they are actively used (Mathieson, 1991). Therefore, a thorough analysis on the reasons for acceptance of information technologies should be conducted to better forecast, identify and improve user acceptance (Davis, Bagozzi \& Warshaw, 1989).

Previous reseaches have determined the pre-determinants of systems acceptance via utilizing various models such as TAM, UTAUT, TTF, TBP, TRA, the first being the most frequently utilized. TAM is a comprehensive theory that explains information systems acceptance (Heijden, 2003). The objective of TAM is to improve the reasoning behind adoption processes and to provide a theoretical approach for the application of information systems (Davis, 1985). Research on TAM focuses on two theoretical structures hypothesized as core determinants of systems usage, namely, PU and PEOU (Davis, 1989). Analogically, various 
empirical tests also validate PU and PEOU as major antecedents of the intention (Venkatesh \& Davis, 2000). In line with these findings, the three main approaches regarding managerial computer usage can be summarized as follows; individuals' intention to use computers can be reasonably forecasted, PU is an important factor of intention, and PEOU is an important secondary factor of intention (Davis et al., 1989).

TAM indicates that belief variables mediate the impacts of external variables on intention (Venkatesh \& Da-vis, 2000), where the latter are known as the antecedents of the former. The better identification and assessment of the pre-determinants of belief structures can contribute to action plans that can facilitate increase of user acceptance. Therefore, studies on information technology usage acceptance / adoption should not be restricted to TAM and the model should be extended to incorporate various external variables to more thoroughly clarify the user acceptance paradigm (Hu, Chau, Sheng \& Tam, 1999). External variables help identify the determinants of PU and PEOU and guides for designing strategies that facilitate usage.

\section{The Effect of Geographical/Regional Differences on E-learning Acceptance}

Performance of an e-learning system can differ according to the cultural identity, socio-economic conditions and the cognitive development of the region it is applied to. Various expectations, attitudes and needs can arise in e-learning platforms that are used by people from different regions and cultural backgrounds. Cultural identities of different nationalities can be reflected in the performance results, creating a variance of user attitudes in technology acceptance and enjoyment per culture. (Roca, Chiu \& Martinez, 2006). Exponential developments in internet and information technologies, globalization, economic improvements and educational investments in developing countries have resulted in the wide-spread usage of e-learning systems, whose distribution regarding the frequency of use is positively skewed towards developing nations (Liu, Liu, Lee \& Magjuka, 2010). Cultural differences may have a negative effect on learners' distance education systems acceptance. Therefore, users' attitudes, expectations, approaches, needs and cultural differences should be considered for the design of a distance education system.

The scientific literature has examined the variety of characteristics users show in e-learning systems. For in-stance, Gaitan, Correa and Cataluna (2011) have investigated the cultural differentiation and technology adoption schemes of users between a European (Spain) and a Latin American (Chile) country, coming to the conclusion that in both of the countries studied, the most robust relationship was the one between the control and PEOU. While the Chilean experiment listed the PEOU-PU relationship as the second strongest, the case differed in Spain where the PEOU-behavioral intention relationship ranked the second. In another case, Joy and Kolb (2009) have examined culture's role in individuals' learning approaches, putting forward that culture has a significant influence in shaping individuals' choices and have an open effect on learning styles.

A myriad of factors, such as cultural and demographic variables usually influence distance education systems. As the speed of globalization of web-based education market accelerates, online education providers' ability to identify and assess the effect of users' varying expectations and cultural values on their learning path will indisputably build up competitive advantage (Liu et al., 2010). An e-learning system designed by taking into account the cultural factors will facilitate the interest of users and their interaction with the system.

The effect of cultural differences may be amplified in the first years of tertiary education where disciplinary conditions are not radiated; hence, academics and trainers should make sure that learning systems incorporate elements that accommodate diversity (Liu et al., 2010). Designing e-learning systems by considering the cultural and demographic conditions of the prospective country, therefore, could not only give rise to efficiencies in learning but also promote solutions for regional problems. Yet, even though the aim to make the most optimal use of cultural and regional diversity in structuring of e-learning systems bears a strategic core, previous research has remained insufficient in encouraging action plans to reduce the concerns arising due to cultural diversity.

\section{METHOD}

This study presents a systematic review of the literature analysing the factors that influence the users' e-learning acceptance (via proposing PU and PEOU as dependent variables) in the Middle Eastern. 44 researches have been identified as a result of the literature review, where 39 of these are publications and the remaining 5 are policy briefs. The reviewed literature has been classified with respect to the country the research has taken place in, the number of participants and the external variables that are tested (Table 1).

The research considered within the scope of this study has taken place in the following countries; Turkey (10), Iran (8), Saudi Arabia (6), Lebanon (5), Jordan (4), Bahrain (3), Egypt (3), Iraq (3), United Arab Emirates (1) and Oman (1). In the studies where Abbas (2016) tests his hypotheses in both Egypt and United Kingdom, and Tarhini, Hone and Liu (2015.a) test their hypotheses in both Lebanon and United Kingdom; only the Middle Eastern components of these research are taken into account.

The major target of this research is to detect the factors that determine the acceptation beliefs of distance education users. Thus, the scope only comprises of the external variables that have been tested to be antecedents of PU and PEOU. These external variables' relationships with other variables in TAM are not considered within the scope of this study.

In the reviewed literature, 45 various variables were identified to have been tested against belief structures in 75 different hypotheses, while some external variables are tested against only one of the belief structures, for 155 times. In the 75 hypotheses investigated, effect of Self Efficacy on PEOU is the most frequently accepted one, as the former's positive and significant influence on the latter has been accepted in 16 of the 18 studies examined, while the other accepted hypotheses with the number of 
acceptance are; Self Efficacy-PU (9), Subjective Norm-PU (9), Anxiety-PEOU (4), Facilitating Conditions-PEOU (4), Subjective NormPEOU (4), Complexity-PEOU (3), Enjoyment-PEOU (3), Facilitating Conditions-PU (3) follow. Embedding the most frequently accepted variables and hypotheses into the model provides a solid foundation for the robustness of the model. Also, this approach is expected to help boost the explanatory power.

Table 1. Studies conducted in the Middle East investigating learner adoption in e-learning systems

\begin{tabular}{|c|c|c|}
\hline Research & Participant & Variables which are tested as antecedent of belief variables (PU or PEOU) \\
\hline Abbad et al. (2009) & 486 & Subjective Norm (R,UT), Experience $(R, A)$, Interactivity $(R, R)$, Self Efficacy $(R, A)$, Tech. Sup. $(A, R)$ \\
\hline Abbas (2016) & 212 & Interpersonel Inf. (A,UT), External Inf. (A,UT), Instructor Inf. (A,A) \\
\hline Abdel-Wahab (2008) & 258 & - \\
\hline Al-Adwan et al. (2013) & 107 & - \\
\hline Al-Azawei and Lundqvist (2015) & 70 & Learning Styles (R,UT), Gender (R,R), Self Efficacy (A,A) \\
\hline Al-Azawei et al. (2017) & 210 & Self Efficacy $(A, A)$, Learning Styles (R,UT) \\
\hline Alenezi (2012) & 408 & - \\
\hline Alenezi et al. (2010) & 408 & - \\
\hline Alenezi et al. (2011) & 408 & - \\
\hline Al-Gahtani (2016) & 286 & $\begin{array}{l}\text { Subjective Norm (A,UT), Image (A,UT), Relevance (A,UT), Demonstrability (R,UT), Self Efficacy (UT,A), } \\
\text { External Control (UT,A), Anxiety (UT,A), Playfulness (UT,R), Enjoyment (UT,A) }\end{array}$ \\
\hline Al-Hawari and Mouakket (2010) & 340 & - \\
\hline Ali et al. (2013) & 425 & Playfulness (UT,A), Self Efficacy (UT,A), Anxiety (UT,A) \\
\hline Al-Mushasha (2013) & 224 & Univer. Sup. $(A, A)$, Efficacy $(A, A)$ \\
\hline Althunibat (2015) & 239 & Facilitating Conditions $(A, A)$, Self Efficacy $(A, A)$ \\
\hline Ameen et al. (2019) & 300 & Technical Support (UT,A) \\
\hline Aypay et al. (2012) & 754 & Facilitating Conditions $(A, A)$, Complexity $(R, A)$, Self Efficacy $(A, R)$ \\
\hline Basheer and Ibrahim (2011). & 799 & - \\
\hline Başoğlu and Özdoğan (2011) & 81 & Mobility (R,UT), Peer Influence (R,UT), Self Efficacy (UT,A), Innovativeness (UT,R), Interface (UT,R) \\
\hline Binyamin et al. (2019) & 833 & $\begin{array}{l}\text { Technical Support (A,A), Learning Support }(A, R) \text {, Visual Design }(R, R) \text {, Navigation }(R, A) \text {, Access }(R, A) \text {, } \\
\text { Interactivity }(A, A) \text {, Assessment }(A, A) \text {, Learnability }(R, A)\end{array}$ \\
\hline Çalışır et al. (2014) & 546 & Image(R,UT), Content Quality(A,UT), Sys. Quality(UT,A), Anxiety (UT,A) \\
\hline Çiğdem and Topçu (2015) & 115 & Subjective Norm $(A, A)$, Complexity $(U T, A)$, Self Efficacy $(R, A)$ \\
\hline Çoşkunçay and Özkan (2013) & 224 & Self Efficacy $(A, A)$, Subjective Norm $(A, A)$, Complexity (UT,A) \\
\hline Farahat (2012) & 153 & Subjective Norm $(A, A)$ \\
\hline Jaflah and Hamad (2008) & 155 & Content $(R, A)$, Self Efficacy $(A, A)$ \\
\hline Jaflah et al. (2014) & 109 & Self Efficacy $(A, A)$, Design (A,UT), Enjoyment (UT,A), Mobility (A,UT), Interectivity $(R, R)$ \\
\hline Karaali et al. (2011) & 546 & Subjecive Norm (A,UT), Facilitating Conditions (UT,A), Anxiety (UT,A) \\
\hline Kılıç et al. (2015) & 416 & Self Efficacy $(A, A)$, Perceived Learning $(A, A)$ \\
\hline Martin (2012) & 210 & $\begin{array}{l}\text { Subjective Norm (A,UT), Extr. Motivation }(R, U T) \text {, Intr. Motivation }(U T, A) \text {, Experience }(A, R) \text {, } \\
\text { Interactivity }(A, R) \text {, Privacy }(U T, R)\end{array}$ \\
\hline Moghadam and Bairamzadeh (2009) & 155 & Subjective Norm (A,UT), Innovativeness (R,A), Self Efficacy (UT,A) \\
\hline Mohammadi (2015.a) & 390 & - \\
\hline Mohammadi (2015.b) & 390 & - \\
\hline Motaghian et al. (2013) & 115 & Information $(A, A)$, System $(R, R)$, Service $(R, A)$, Subjective Norm $(A, A)$, Self Efficacy $(R, A)$ \\
\hline Mohammadi i et al. (2008) & 120 & Experience (A,R), Anxiety (UT,R), Age (R,UT), Self Efficacy (UT,R), Affect (UT,R) \\
\hline Sadeghi et al. (2014) & 275 & Masculinity $(A, A)$, Uncertainty Avoidance $(A, A)$, Individualism $(A, R)$, Power Distance $(A, A)$ \\
\hline Sezer and Yılmaz (2019) & 515 & - \\
\hline Seif et al. (2013) & 120 & Pleasure seeking $(A, A)$, Applicability $(A, A)$ \\
\hline Tarhini et al. (2013) & 569 & - \\
\hline Tarhini et al. (2014) & 569 & - \\
\hline Tarhini et al. (2015.a) & 596 & - \\
\hline Tarhini et al. (2015.b) & 235 & - \\
\hline Tarhini et al. (2017) & 569 & - \\
\hline Ursavaş (2015) & 311 & - \\
\hline Yalçın ve Kutlu (2019) & 282 & Social Norm (A,UT), User Inteface Design (R,A), Computer Self Efficacy $(R, A)$ \\
\hline Zare and Yazdanparast (2013) & 379 & Playfulness (UT,A), Enjoyment $(A, A)$, Facilitating Conditions $(A, A)$, Cognitive Absorption $(A, A)$ \\
\hline
\end{tabular}

Kayan, Fussell and Setlock (2006) indicate that different cultures give rise to different styles of information technology usage and assess these differences between Eastern and Western societies within the individualism-collectivism axis. They put forward the opinion that individualist Western societies are emphasized by taking personal initiatives and independence, while collectivist 
Eastern culture is structured upon group-work and a collective identity. Thus, one can easily presume that users from Eastern cultures shaped by collectively associate a relatively greater value to interaction, helping the variable to have a more important impact on user acceptance. Nevertheless, literature reviewed within the scope of the story did not support this hypothesis, and therefore, the variable in question has not been added into the proposed model, creating a question to be debated for further research.

Mohammadi (2015.a) claims that Eastern users have relatively greater social inclination compared to their Western colleagues and emphasizes the criticality of social factors (image, mobility, innovativeness and subjective norm) in explaining e-learning systems acceptance. Subjective Norm has been tested in the reviewed literature quite frequently as the relationship between Subjective Norm and PU is the third most frequently tested and accepted among all hypotheses assessed, bearing an acceptance ratio of $90 \%$. Moreover, the proposal that Subjective Norm influences PEOU in a significant and positive manner has been approved in all 4 studies, therefore both of these hypotheses are incorporated into the proposed model.

\section{RESULTS}

The 6 external variables that are most frequently accepted in the literature are Self Efficacy, Subjective Norm, Facilitating Conditions, Anxiety, Complexity and Enjoyment. The proposed model includes 12 hypotheses 9 of which test the effects of external variables on the two belief variables.

\section{Self Efficacy}

Self-Efficacy is a self-perception of a person's capacity to fulfil a particular task (Bandura, 1982). Within the scope of this research, Self Efficacy is considered as a learner's judgement on her / his ability to study via utilizing the e-learning system.

Self Efficacy theory projects that individuals who believe they sustain the necessary skills for success will display a relatively higher performance (Barling \& Beattie, 1983).Therefore, from an distance learning perspective, it is highly likely that users with high Self Efficacy will perceive themselves to be more successful in utilizing the system (Hsia, Chang \& Tseng, 2014).

A myriad of research has integrated Self Efficacy into TAM to examine its effects on user beliefs. In the literature review, it was seen that the hypothesis that Self Efficacy influences PEOU was accepted in 16 of 18 examined studies. The hypothesis that Self Efficacy influences PU was also accepted in 9 of the 13 hypotheses.

It is possible that a user with an elevated Self Efficacy will presume the circumvention of possible obstacles of e-learning systems usage and expect to benefit from this system.

\section{Subjective Norm}

The subjective norm is the perception that the people that an individual cares about should or should not perform an action (Venkatesh \& Davis, 2000). In this study, Subjective Norm is evaluated as the social pressure perceived by user to use the distance learning system.

Subjective Norm's position regarding whether it is a direct or indirect determinant of information technologies usage is unclear and is a highly debated subject. Davis et al. (1989) opinionated that Subjective Norm does not have a direct effect on intention and hence, TAM does not incorporate this variable as a premise of intention. Even though this study proposes Subjective Norm's indirect influence on intention, the lack of any social variable on TAM can give rise to problems as these social variables can prove helpful in shedding light on unexplained conditions. In line with this view, TAM 2 theorizes that Subjective Norm influences intention through PU.

In the reviewed literature, the hypothesis that Subjective Norm affects PU was accepted in 9 of 10 studies tested. The hypothesis that Subjective Norm affects PEOU was accepted in all four studies examining this hypothesis. Views about whether or not to use an e-learning application are likely to have an impact on the student's perception that the system is useful or easy to use.

\section{Facilitating Conditions}

Facilitating Conditions is the degree that a user believes in the prevalence of an organizational infrastructure for the facilitation of user's system utilization. It is simply the appropriateness of the aide and support given to an individual for technology integration (Teo, 2011) and it represents the organizational support that expedites the information technology usage (Venkatesh \& Bala, 2008). Giving support to an individual for her computer usage can ameliorate the systems usage (Thompson, Higgins \& Howell, 1991) and a lack of support in infrastructure is a seminal setback in the application of e-learning systems.

Some of the potential obstacles are mitigated or eliminated if users are educated or helped upon facing problems. It is widely thought that the provision of support is critical in the adoption of technologies regarding pedagogical applications (Groves \& Zemel, 2000). Facilitating Conditions is proposed as an antecedent of Use Behaviour in unified theory of acceptance and usage of technology.

All of the four studies testing this external factor accept the hypothesis that Facilitating Conditions significantly and positively influence users' PEOU for e-learning systems. Three studies that investigate the relationship between this variable and PU find out a significant relationship. Facilitating Conditions will mitigate the necessary cognitive effort to be spared for interacting with 
information and communication technologies and hence, will boost the positive perception regarding the system's userfriendliness (Moreno, Cavazotte \& Alves, 2017). Moreover, users' belief that an organizational infrastructure facilitating the elearning systems usage exists will positively influence the perception regarding the system's usefulness.

\section{Anxiety}

Anxiety is defined as reacting emotionally or worried upon undertaking an activity (Venkatesh et al., 2003). Computer Anxiety, therefore, is expected to capture the emotional side of technology usage (Venkatesh, 2000). This term can simply be described as an individual's worry or Anxiety about information systems usage (Igbaria \& Parasuraman, 1989). Computer Anxiety reflects the emotional distress an individual faces upon computer technology utilization (Igbaria \& livari, 1995).

An acclaimed research group specializing in information technologies and psychology emphasizes the importance of independent variables such as Computer Anxiety on strategically dependent variables (Venkatesh, 2000). This term was also proposed to be a determinant of PEOU in TAM 3 (Venkatesh \& Bala, 2008). Anxiety or similar emotions can affect efficiency, social relations, general welfare and learning (Saade \& Kira, 2006). A high level of Anxiety may result in a lower level of learning satisfaction (Purnomo \& Lee, 2012).

The reviewed literature shows that 4 out of 5 studies examining the relationship between Anxiety and PEOU find a negative relationship between these two variables. If the usage of information technologies agitates the user, it can trigger an unfortunate perception regarding the system's complexity (Raaij \& Schepers, 2008). Hence it is highly likely that a worrisome or anxious user can see the e-learning system as difficult and complicated.

\section{Complexity}

Complexity is the degree of difficulty perceived to understand and undertake a certain innovation (Thompson et al., 1991). It can easily be deducted that the less complex a system is, the easier it is for an individual to adopt it. Diffusion of Innovation Theory bears resemblance to TAM, as the relative advantage and complexity factors show similarities with PU and PEOU, respectively (Veloo \& Masood, 2014). If usage of personal computers is analysed from an innovation acceptance perspective, one can speculate of an inverse relationship between Complexity and usage (Thompson et al., 1991).

Literature on e-learning acceptance also investigates the relationship between Complexity of Innovation Diffusion Theory and PEOU of TAM. All of the three studies testing this external factor accept a negative influence of Technological Complexity on PEOU, reaffirming the opinion that if a user regards an e-learning system as complex, it will perceive its usage to be difficult as well.

\section{Enjoyment}

Enjoyment is defined as the degree of perceiving a technology as enjoyable without considering performance results (Davis, Bagozzi \& Warshaw, 1992). From an internal motivation perspective, actions are triggered by pleasure, joy and fun. Enjoyment is regarded as a vital component of internal motivation and it significantly influences user acceptance (Huang, Lin \& Chuang, 2007). Perceived Enjoyment has been conceptualized as a PEOU determinant whose effect gradually accrues as the users' experience with the system increase (Venkatesh, 2000).

With the rise of the hedonistic technologies such as online games, there is a surge in the attention given to the concept of Enjoyment, since individuals enjoying using a certain system are more likely to accept that system (Park, Son \& Kim, 2012). They tend to underestimate the complexities of the system and believe to spare relatively less effort in the utilization of the system compared to their alternatives (Venkatesh, 2000).

All the three studies testing Enjoyment accept a relationship between Enjoyment and PEOU. It is expected that a user deeming an e-learning system as enjoyable regardless of the performance output will have an affirmative perception on the convenience of use of the system.

TAM theorizes PEOU as a direct determinant of PU, since a user's perception of simplicity can affect his/her notion regarding the practicality of the system (Vijayasarathy, 2004). PEOU affects intention both directly and through its impact on PU (Venkatesh \& Davis, 2000). An individual's perception that an e-learning system is user-friendly can influence her opinion on the efficacy of the system. In addition, it is also likely that the user-friendliness and favourability of the system can determine the intention to use.

TAM should be expanded in accordance with the content of the subject since it does not involve social processes and lacks the power of explanation. The development of the model with various external variables is an expected study topic (Sumak et al., 2011). Therefore, the proposed model is an extended version of TAM with the addition of various external variables based on the literature review. However, whether the attitude variable in the TAM mediates the effect of belief variables on intention is a controversial issue in the literature (Baki, Birgören \& Aktepe, 2018). The attitude cannot clarify the causal link between variables (Davis et al. 1989). Therefore, attitude variable was not included in the proposed model. The most commonly accepted hypotheses to affect belief structures were identified and these hypotheses were included in TAM. 


\section{CONCLUSIONS AND RECOMMENDATIONS}

E-learning systems have become an indispensable part of education services and are being extensively used in a wide span of geographical regions, hence it is important to specify the factors that affect the acceptance of systems. These factors can vary with respect to the cultural identities of users. This study analysed the results of 44 different studies investigating users' e-learning acceptance in the Middle East via the use of TAM; the current literature lacks such a region-based analysis. Hypotheses mostly accepted in these studies are identified and included into an extended TAM.

The reviewed literature includes 45 different variables as antecedents of TAM's belief variables and 75 hypotheses test their relationship with the belief structures PU and PEOU. The most commonly accepted hypotheses have been identified. As a result, 6 external variables and 9 hypotheses that investigate their relationships with the belief structures are integrated into TAM and an extended model has been proposed as shown in Figure 1.

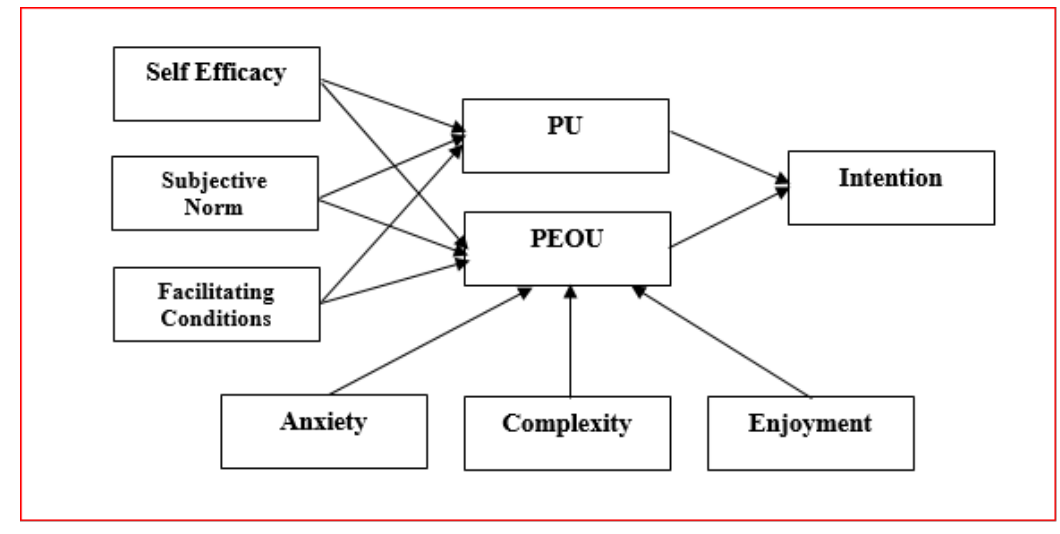

\section{Figure 1. Proposed Model}

In his study, Mohammadi (2015.a) emphasized that users in eastern culture have more social orientation than those in the west, and therefore the concept of subjective norms should receive more attention. In most of the studies examined, Subjective Norm has a positive impact on user beliefs. In the research conducted by Baki, Aktepe \& Birgören (2019), it was stated that the high Self Efficacy belief of users in the Middle East influenced e-learning system acceptance. The results of the study confirm this statement. Also, Baki et al. (2019) showed as a result of their literature review, that Playfulness (high degree of ability to do anything that user wants to do in the system), which is a major factor in the system acceptance of users in the Europe-Central Asia region, is not frequently tested in the Middle East region. When tested in future studies, it may be shown to have a significant impact.

It has been identified that the factors of Self Efficacy and Subjective Norm are especially effective in the systems acceptance of Middle Eastern users. System developers should try to maintain student confidence. Educational institutions can improve Self Efficacy of students with videos introducing the system and demonstrating that the use of system is not difficult. Moreover, these applications should also take into account the social pressure users feel on their utilization of the systems.

This research proposes that an empirical test of the model on the Middle Eastern users should be conducted as a next step. Moreover, further research should focus on studies conducted in developing regions such as East Asia and South America regarding user behaviour.

\section{REFERENCES}

Abbad, M.M., Morris, D., Nahlik, C.D. (2009). Looking under the bonnet: factors affecting student adoption of e-Learning systems in Jordan. International Review of Research in Open and Distance Learning, 10(2), 1-15.

Abbas, T. (2016). Social factors affecting students' acceptance of e-learning environments in developing and developed countries A Structural Equation Modelling approach. Journal of Hospitality and Tourism Technology,7(2), 200-212.

Abdel-Wahap, A.G., (2008). Modelling student's intention to adopt e-learning a case from Egypt. The Electronical Journal of Information Systems in Developing Countries, 34(1), 1-13

Al-Adwan, A., Al-Adwan, A., Smedley, J. (2013). Exploring student's acceptance of e-learning using Technology Acceptance Model in Jordanian universities. International Journal of Education and Development using Information and Communication Technology, 9(2), 4-18.

Al-Azawei, A., Lundqvist, K. (2015). Learner differences in perceived satisfaction of an online learning: An extension to the Technology Acceptance Model in an Arabic sample. The Electronic Journal of e-Learning, 13(5), 408-426.

Al-Azawei, A., Parslow, P., Lundqvist, K. (2017). Investigating the effect of learning styles in a blended e-learning system: An extension of the Technology Acceptance Model (TAM). Australasian Journal of Educational Technology, 33(2), 1-23.

Alenezi, A. R. (2012). E-learning acceptance: technological key factors for the successful students' engagement in e-learning system. The 2012 International Conference on e-Learning, e-Business, Enterprise Information Systems, and e-Government, 16-19. 
Alenezi, A.R., Karim, A.M.A., Veloo, A. (2010). An empirical investigation into the role of enjoyment, computer anxiety, computer Self Efficacy and internet experience in influencing the students' intention to use e-learning: A case study from Saudi Arabian Governmental Universities. The Turkish Online Journal of Educational Technology, 9(4), 22-34.

Alenezi, A.R., Karim, A.M.A., Veloo, A. (2011). Institutional support and e-learning acceptance: an extension of the Technology Acceptance Model. International Journal of Instructional Technology and Distance Learning, 8(2), 3-16.

Al-Gahtani, S.S. (2016). Empirical investigation of e-learning acceptance and assimilation: A Structural Equation Model. Ap-plied Computing and Informatics, 12, 27-50.

Al-Hawari. M.A., Mouakket, S. (2010). The influence of Technology Acceptance Model (TAM) factors on students' e-satisfaction and e-retention within the context of UAE e-learning. Education, Business and Society: Contemporary Middle Eastern Issues, 3(4), 299 - 314.

Ali, H., Ahmed, A.A., Tariq, T.G., Safdar, H. (2013). Second life (SL) in education: The intensions to use at university of Bah-rain. In Fourth International Conference on e-Learning Best Practices in Management, Design and Development of e-Courses: Standards of Excellence and Creativity, 205-215.

Al-Mushasha, N. F. (2013). Determinants of e-learning acceptance in higher education environment based on extended Technology Acceptance Model. In Fourth International Conference on E-learning Best Practices in Management, Design and Development of E-courses: Standards of Excellence and Creativity, 261-266.

Althunibat, A. (2015). Determining the factors influencing students' intention to use m-learning in Jordan higher education. Computers in Human. Behaviour, 65-71.

Ameen, N., Willis, R., Abdullah, M. N., \& Shah, M. (2019). Towards the successful integration of e-learning systems in higher education in Iraq: A student perspective. British Journal of Educational Technology, 50(3), 1434-1446.

Aypay, A., Çelik, H.C., Aypay, A., Sever, M. (2012). Technology acceptance in education: A study of pre-service teachers in Turkey. Turkish Online Journal of Educational Technology, 11(4), 264-272.

Baki, R. (2019). The Impact of Information Technologies and Top Management Support on Supply Chain Performance: An Empirical Approach for Turkey. European Journal of Science and Technology, (17), 916-926.

Baki, R., Aktepe, A., \& Birgören, B. (2019). Factors affecting the acceptance of e-learning for users with respect to user type, region, culture, welfare and development levels. MANAS Journal of Social Studies, 8(2), 2214-2242.

Baki, R., Birgoren, B. \& Aktepe, A. (2018). A meta-analysis of factors affecting perceived usefulness and perceived ease of use in the adoption of e-learning systems. Turkish Online Journal of Distance Education, 19(4), 4-42.

Bandura, A. (1982). Self Efficacy mechanism in human agency. American Psychologist, 37, 12-147.

Barling, J., Beattie, R. (1983). Self Efficacy beliefs and sales performance. Journal of Organizational Behaviour Management, 5, $41-51$.

Basheer, A.A., Ibrahim, A.M.A. (2011). Measuring the acceptance and adoption of e-learning by academic staff. Knowledge Management \& ELearning: An International Journal, 3(2), 201.

Başoğlu, N., Özdoğan, M.K. (2011). Exploring the major determinants of mobile learning adaption. Boğaziçi University Journal of Education, 28(1), 31-46.

Binyamin, S. S., Rutter, M. J., \& Smith, S. (2019). Extending the Technology Acceptance Model to Understand Students' use of Learning Management Systems in Saudi Higher Education. International Journal of Emerging Technologies in Learning, 14(3), 4-21.

Çalışır, F., Gümüşsoy, Ç.A., Bayraktaroglu, A.E., Karaali, D. (2014). Predicting the intention to use a web-based learning system: Perceived content quality, anxiety, perceived system quality, image, and the Technology Acceptance Model. Human Factors and Ergonomics in Manufacturing \& Service Industries, 24(5), 515-531.

Çiğdem, H., Topçu, A. (2015). Predictors of instructors' behavioural intention to use learning management system: A Turkish vocational college example. Computers in Human Behaviour, 52, 22-28.

Çoşkunçay, D.F., Özkan, S. (2013). A model for instructors' adoption of learning management systems: empirical validation in higher education context. The Turkish Online Journal of Educational Technology, 12(2), 13-25.

Davis, F.D. (1985). A Technology Acceptance Model for empirically testing new end-user information systems: Theory and result (Published PhD thesis). Massachusetts Institute of Technology, U.S.A.

Davis, F.D. (1989). Perceived usefulness, perceived ease of use, and user acceptance of information technology. MIS Quarterly, 13 (3), $319-340$.

Davis, F.D., Bagozzi, R.P., Warshaw, P.R. (1989). User acceptance of computer technology: A comparison of two theoretical models. Management Science, 35 (8), 982-1003.

Davis, F.D., Bagozzi, R.P., Warshaw, P.R. (1992). Extrinsic and intrinsic motivation to use computers in the workplace. Journal of applied social psychology. 22(14), 1111-1132.

Docebo. (2016). E-Learning market trends and forecast 2017-2021. Retrieved from https://www.docebo.com/resource/elearning-markettrends-and-forecast-2017-2021/

Farahat, T. (2012). Applying the Technology Acceptance Model to online learning in the Egyptian universities. Procedia-Social and Behavioural Sciences, 64, $95-104$.

Gaitan, A.J., Correa, R.P.E., Cataluna, R.F.J. (2011). Cross cultural analysis of the use and perceptions of web-based learning systems. Computers \& Education, $57,1762-1774$.

Groves, M. M., Zemel, P. C. (2000). Instructional technology adoption in higher education: An action research case study. Inter-national Journal of Instructional Media, 27(1), 57-65. 
Heijden, H.V.D. (2003). Factors influencing the usage of websites: The case of a generic portal in The Netherlands. Information \& Management, 40, 541-549.

Hu, P.J., Chau, P.Y.K., Sheng, O.R.L., Tam, K.Y. (1999). Examining the Technology Acceptance Model using physician ac-acceptance of telemedicine technology. Journal of Management Information Systems, 16 (2), 91-112.

Huang, J.H., Lin, Y.R., Chuang, S.T. (2007). Elucidating user behaviour of mobile learning: A perspective of the extended Technology Acceptance Model. The Electronic Library, 25(59), 585-598.

Hsia, J.W., Chang, C.C., Tseng, A.H. (2014). Effects of individuals' locus of control and computer Self Efficacy on their e-learning acceptance in high-tech companies. Behaviour \& Information Technology, 33(1), 51-64.

Igbaria, M., livari, J. (1995). The effects of Self Efficacy on computer usage. Omega, 23(6), 587-605.

Igbaria, M., Parasuraman, S. (1989). A path analytic study of individual characteristics, computer anxiety and attitudes toward microcomputers. Journal Management, 15(3), 373-388.

Jaflah, H.A., Al-Sherooqi, A.H., Al-Sherooqi, H.K. (2014). The acceptance of social networking as a learning tools at university of Bahrain. International Journal of Information and Education Technology. 4(2), 208-214.

Jaflah, A., Hamad, S. (2008). Factors influencing the adoption of e-learning at University of Bahrain. Second International Conference and Exhibition for Zain E-learning Center, 28-30.

Joy, S., Kolb, D.A. (2009). Are there cultural differences in learning style? International Journal of Intercultural Relations, 33, 69-85.

Karahanna, E., Straub, D.W., Chervany, N.L. (1999). Information technology adoption across time: A cross-sectional comparison of pre-adoption and post-adoption beliefs. MIS Quarterly, 23 (2), 83-213.

Karaali, D., Gümüşsoy, C.A., Çalışır, F. (2011). Factors affecting the intention to use a web-based learning system among blue-collar workers in the automotive industry. Computers in Human Behaviour. 27, 343-354.

Kayan, S., Fussell, S.R., Setlock, L.D. (2006). Cultural Differences in the Use of Instant Messaging in Asia and North America, Computer Supported Cooperative Work (CSCW) 2006, Banff, Alberta-Canada, 525-528.

Kelly, T.M., Diane K.B. (2003). Managing intellectual capital-Via e-learning-At Cisco. Handbook on knowledge management. Springer Berlin Heidelberg. 511-532.

Kılıç, E., Güler, Ç., Çelik, H.E., Tatli, C. (2015). Learning with interactive whiteboards determining the factors on promoting interactive whiteboards to students by Technology Acceptance Model. Interactive Technology and Smart Education, 12(4), 285-297.

Lee, B.C., Yoon, J.O., Lee, I. (2009). Learners' acceptance of e-learning in South Korea: Theories and results. Computers \& Education, 53, 13201329.

Legris, P., Ingham, J., Collerette, P. (2003). Why do people use information technology? A critical review of the Technology Acceptance Model. Information \& Management, 40(3), 191-204.

Liu, X., Liu, S., Lee, S., Magjuka, R.J. (2010). Cultural differences in online learning: International student perceptions. Journal of Educational Technology \& Society, 13(3), 177-188.

Martin, R. G. (2012). Factors affecting the usefulness of social networking in e-learning at German university of technology in Oman. International Journal of e-Education, e-Business, e Management and e-Learning, 2(6), 498-502.

Mathieson, K. (1991). Predicting user intentions: Comparing the Technology Acceptance Model with the theory of planned behaviour. Information Systems Research, 2(3), 173-191.

Moghadam, A.H., Bairamzadeh, S. (2009). Extending the Technology Acceptance Model for e-learning: A case study of Iran. In the Sixth International Conference on Information Technology: New Generations, 1659-1660.

Mohammadi, H. (2015.a). Investigating users' perspectives on e-learning: An integration of TAM and IS success model. Computers in Human Behaviour, 45, 359-374.

Mohammadi, H. (2015.b). Factors affecting the e-learning outcomes: An integration of TAM and IS success model. Telematics and Informatics, 32, 701-719.

Moreno, V., Cavazotte, F., Alves, I. (2017). Explaining university students' effective use of e-learning platforms. British Journal of Educational Technology, 48(4), 995-1009.

Motaghian, H., Hassanzadeh, A., Moghadam, D.K. (2013). Factors affecting university instructors' adoption of web-based learning systems: Case study of Iran. Computers \& Education, 61, 158-167.

Pantezis, C. (2002). Maximizing e-learning to train the 21 st. century workforce. Public Personnel Management, 31(1), 21-26.

Park, Y., Son, H., Kim, C. (2012). Investigating the determinants of construction professionals' acceptance of web-based training: an extension of the Technology Acceptance Model. Automation in Construction, 22, 377-386.

Pituch, K.A., Lee, Y.K. (2006). The influence of system characteristics on e-learning use. Computers \& Education, 47, $222-244$.

Purnomo, S.H., Lee, Y.H. (2012). E-learning adoption in the banking workplace in Indonesia: An empirical study. Information Development, 29(2), 138-153.

Raaij, E. M. V., \& Schepers, J. J. (2008). The acceptance and use of a virtual learning environment in China. Computers \& Education, 50(3), 838852.

Rezaei, M., Mohammadi, H.M., Asadi, A., Kalantary, K. (2008). Predicting e-learning application in agricultural higher education using Technology Acceptance Model. Turkish Online Journal of Distance Education, 98(1), 85-85.

Roca, J.C., Chiu, C.M., Martinez, F.J. (2006). Understanding e-learning continuance intention: An extension of the Technology Acceptance Model. International Journal of Human-Computer Studies, 64, 683-696. 
Rogers, E.M. (1983). Diffusion of Innovation, Third Ed., The Free Press, New York.

Saade, R.G., Kira, D. (2006). The emotional state of technology acceptance. Issues in Informing Science and Information Technology, 3(1), 529539.

Sadeghi, K., Saribagloo, J.A., Aghdam, S.H., Mahmoudi, H. (2014). The impact of Iranian teachers' cultural values on computer technology acceptance. The Turkish Online Journal of Educational Technology, 13(4), 124-136.

Seif, M.H., Rastegar, A., Ardakani, S.J.H., Saeedikiya, M. (2013). Factors influencing intention to use and application of web-based learning among students of Shiraz Payame Noor University (providing a path analysis model). Journal of Basic and Ap-plied Scientific Research, 3(2), 848852.

Sezer, B., \& Yilmaz, R. (2019). Learning management system acceptance scale (LMSAS): A validity and reliability study. Australasian Journal of Educational Technology, 35(3), 15-30.

Sumak, B., Hericko, M., Pusnik, M. (2011). A meta-analysis of e-learning technology acceptance: The role of user types and e-learning technology types. Computers in Human Behaviour, 27, 2067-2077.

Tarhini, A., Hassouna, M., Abbasi, M.S., Orozco, J. (2015). Towards the acceptance of RSS to support learning: An empirical study to validate the Technology Acceptance Model in Lebanon. Electronic Journal of e-Learning Volume, 13(1), 30-41.

Tarhini, A., Hone, K., Liu, X. (2013). Factors affecting students' acceptance of e-learning environments in developing countries: A structural equation modelling approach. International Journal of Information and Education Technology, 3(1), 54-59.

Tarhini, A., Hone, K., Liu, X. (2014) The effects of individual differences on e-learning users' behaviour in developing countries: A structural equation model. Computers in Human Behaviour, 41, 153-163.

Tarhini, A., Hone, K., Liu, X. (2015). A cross-cultural examination of the impact of social, organisational and individual factors on educational technology acceptance between British and Lebanese university students. British Journal of Educational Technology, 46(4), 739-755.

Tarhini, A., Hone, K., Liu, X., Tarhini, T. (2017). Examining the moderating effect of individual-level cultural values on users' acceptance of Elearning in developing countries: A structural equation modelling of an extended Technology Acceptance Model. Interactive Learning Environments, 25(3).

Teo, T. (2011). Modelling the determinants of pre-service teachers' perceived usefulness of e-learning. Campus-Wide Information Systems, 28(2), $124-140$.

Thompson, R.L. Higgins, C.A. Howell, J.M. (1991). Personal Computing: Toward a Conceptual Model of Utilization. MIS Quarterly, 15(1), 125-143.

Trentin, G. (1997). Telematics and online teacher training: The POLARIS project. Journal of Computer Assisted Learning, 13, $261-270$.

Ursavaş, Ö.F. (2015). The Influence of Hedonic and Utilitarian Motivations on Teachers Behavioural Intention to Use Tablet PCs. Education and Science, 40, 25-43.

Veloo, R., Masood, M. (2014). Acceptance and intention to use the I-learn system in an automotive semiconductor company in the northern region of Malaysia. Procedia-Social and Behavioural Sciences, 116, 1378- 1382.

Venkatesh, V. (2000). Determinants of perceived ease of use: Integrating control, intrinsic motivation, and emotion into the Technology Acceptance Model. Information Systems Research, 11(4), 342-365.

Venkatesh., V., Bala., H. (2008). Technology Acceptance Model 3 and a research agenda on interventions. Decision Sciences, 39(2), 273-315.

Venkatesh, V., Davis, F.D. (2000). A theoretical extension of the Technology Acceptance Model: Four longitudinal field studies. Management Science, 46 (2), 186-204.

Venkatesh, V., Morris, M.G., Davis, G.B., Davis, F.D. (2003). User acceptance of Information Technology: Toward a unified view. MIS Quarterly, $27(3), 425-478$

Vijayasarathy, L. R. (2004). Predicting consumer intentions to use online shopping: The case for an augmented Technology Acceptance Model. Information and Management, 41, 747-762.

Yalcin, E.M., \& Kutlu, B. (2019). Examination of students' acceptance of and intention to use learning management systems using extended TAM. British Journal of Educational Technology, 50(5), 2414-2432.

Zare, H., \& Yazdanparast, S. (2013). The causal Model of effective factors on intention to use of information technology among payamnoor and traditional universities students. Life Science Journal, 10(2), 46-50. 